\title{
Social Stress at Work and Change in Women's Body Weight
}

\author{
Maria U. KOTTWITZ ${ }^{1,2}$, Simone GREBNER ${ }^{1}$, Norbert K. SEMMER ${ }^{1,4}$, \\ Franziska TSCHAN ${ }^{3,4}$ and Achim ELFERING ${ }^{1,4} *$
}

\footnotetext{
${ }^{1}$ Department of Work and Organisational Psychology, Institute of Psychology, University of Berne, Switzerland

${ }^{2}$ Department of Work and Organisational Psychology, Psychology, Institute of Psychology, University of Marburg, Germany

${ }^{3}$ Department of Psychology, University of Neuchâtel, Switzerland

${ }^{4}$ National Centre of Competence in Research, Affective Sciences, University of Geneva, Switzerland
}

Received August 7, 2013 and accepted December 9, 2013

Published online in J-STAGE January 15, 2014

\begin{abstract}
Social stressors at work (such as conflict or animosities) imply disrespect or a lack of appreciation and thus a threat to self. Stress induced by this offence to self might result, over time, in a change in body weight. The current study investigated the impact of changing working conditions - specifically social stressors, demands, and control at work- on women's change in weighted Body-Mass-Index over the course of a year. Fifty-seven women in their first year of occupational life participated at baseline and thirty-eight at follow-up. Working conditions were assessed by self-reports and observer-ratings. Body-Mass-Index at baseline and change in Body-Mass-Index one year later were regressed on self-reported social stressors as well as observed work stressors, observed job control, and their interaction. Seen individually, social stressors at work predicted Body-Mass-Index. Moreover, increase in social stressors and decrease of job control during the first year of occupational life predicted increase in Body-Mass-Index. Work redesign that reduces social stressors at work and increases job control could help to prevent obesity epidemic.
\end{abstract}

Key words: BMI, Job control, Occupational stress, Social stressors, Work observation

\section{Introduction}

Being overweight and obesity have become an increasing problem of modern society ${ }^{1}$. Previous research has shown high levels of Body-Mass-Index (BMI) to be a risk factor for impaired well-being ${ }^{2-4)}$ and health ${ }^{5-8)}$. Additionally, being overweight and obesity are associated with considerable costs in the workplace ${ }^{9,10)}$, direct medical costs and indirect costs following disability retirement ${ }^{11,12)}$ or

*To whom correspondence should be addressed.

E-mail: achim.elfering@psy.unibe.ch

(C)2014 National Institute of Occupational Safety and Health occupational injuries ${ }^{13)}$.

Stress might be an important factor in the development of obesity $^{1,14-16)}$. Research on work stress and BMI mainly focused on two stress models - the job demand-control (JDC) model $^{17)}$ and the effort-reward imbalance (ERI) model $^{18)}$ - with only limited evidence ${ }^{19-23)}$. In general, a recent meta-analysis of longitudinal studies of stress and adiposity found work-related stress to be associated with increasing adiposity ${ }^{24)}$. Moreover, several psychosocial work factors predict changes in $\mathrm{BMI}^{25,26)}$. Nevertheless, effects are rather small and results are heterogeneous ${ }^{24)}$. Thus, future longitudinal research that includes change in body weight should rely on objective weight measurement 
and objective assessment of work conditions to reduce mono-method bias ${ }^{27)}$.

So far, work-related social stressors (social animosities, conflicts with co-workers and supervisors, unfair behaviour, and negative group climate ${ }^{28)}$ have largely been neglected in this context. Recently, Berset et al. highlighted the role of social stressors as a direct threat to an individual's need of belongingness ${ }^{29)}$. They analysed the effects of social stressors, JDC and ERI models, and found that social stressors at work negatively influence a person's BMI, and a person's control over work situation are positively associated with BMI two years later. However, both stressors and BMI measures relied on self-report, implying the danger of inflated effects due to common method variance ${ }^{27,30-32)}$.

Therefore, the present longitudinal pilot study focused on self-reports of social stressors at work as well as observer-rated work stressors and job control to predict changes in women's BMI. We want to extend previous research by including: a) observer-rated job demands and control, as well as self-reported social stressors; b) a longitudinal design with a time lag of one year; c) change in BMI predicted by change in work stressors; and d) to avoid the healthy worker effect, include female employees in the first months of their occupational life ${ }^{33,34)}$. The healthy worker effect is especially important as persons who have developed impaired well-being might quit or be assigned to less stressful activities thus, underestimating the impact of work stress ${ }^{33,34)}$.

We expect change in BMI to be positively associated with change in social stressors (hypothesis 1). Additionally, we expect it to be positively associated with change in work stressors (hypothesis 2.1) and negatively associated with change in job control (hypothesis 2.2). According to the JDC model we expect a significant interaction between work stressors and job control showing a buffering effect of job control in the association between job stressors and BMI (hypothesis 2.3).

\section{Subjects and Methods}

\section{Participants and design}

The data refers to a large-scale questionnaire study on working conditions and quality of life of young workers in Switzerland ${ }^{35)}$. In the core project at Time 1, 1,394 apprentices were recruited from vocational schools in the German and French speaking areas of Switzerland in the last months before final exams. For this particular subsample all German-speaking participants $(\mathrm{n}=802, \mathrm{n}=$
395 female) were addressed. They received an information letter and consent form including a prepaid envelope. As incentive to participate in the current study a lottery with different prices was announced (e.g., small amounts of money, vouchers for clothes or compact discs etc.). In case of agreement to participate, subsequently, supervisors of employed participants received an information letter and were contacted by phone to give informed consent and to schedule data collection. In each wave, participants were observed by trained raters as well as asked to complete questionnaires and interviews. Measurements at work were conducted with the least impairment of daily working routine as possible. However, it is a very intense study design (from the raters as well as participants points of view) and due to work place observations, the agreement of the supervisors was essential. At Time 1, 93 entrants (61 women and 32 men) agreed to participate, thus 11.6\% of the German speaking participants in the core project were willing to also participate in the present study. The present analyses refer to the female subsample due to the small number of male participants and the influence of gender on BMI reactivity ${ }^{21,36)}$. Altogether 57 women and their supervisors from four occupations within the service work sector (nurses, cooks, sales persons, and bank clerks) voluntarily participated in first BMI measurement in the first six months after finishing vocational training $(M=3.96$ months, $S D=2.84$ ). Two women were excluded from regression analyses due to missing observational data. At time of the first measurement, participants were employed in 35 different low-, medium- and large-size organizations located in rural and urban areas of the Swiss speaking parts of Switzerland. Mean age was $22.47 \mathrm{yr}(S D=3.63)$. Of those, 38 (67\%) took part in the follow-up survey one year later.

\section{Ethics}

The study was performed in consensus with all requirements defined by the Swiss Society of Psychology, including participants information about their rights and guarantee of anonymity. Informed consent of participants (and supervisors in the case of observation at work) was obtained.

\section{Measures}

Job demand-control model. According to the JDC mod$\mathrm{el}^{17)}$ job strain arises when employees simultaneously have high job demands and a low level of control over work. We used the observer version of the Instrument for Stress Oriented Task Analysis ${ }^{37)}$. Raters were trained intensively. 
Ratings were based on an observation period of $60 \mathrm{~min}$ plus three additional time-samples of 15 min each. Rated items were related to frequency or intensity of job characteristics on 5-point Likert-scales. In occupational health research, the demands component of the model most often included time pressure or role conflict ${ }^{38)}$. We therefore conceptualised job demands by time pressure (e.g., high work pace; three items). Cronbach's alpha ranged between 0.74 and 0.86 . Job control was measured by rating method control (e.g., independently plan and organize their own work; four items); Cronbach's alpha ranged between 0.79 and 0.86 . Observation was complemented by an interview with the jobholder (30-45 min), questions to supervisor(s) and colleague(s), and consultation of organizational documents, if necessary. The interviews were conducted using an interview guide with key questions for each dimension and served the purpose of obtaining an overview of the sequence of task conduct, verification of observer impressions and enhancement of comprehension. When observations were incomplete missing observational data were inputted with information provided by observation interview data and self-report (16\%). Observations and interviews were conducted and completed during one working day (Tuesday, Wednesday, or Thursday). In order to reduce potential effects from the observation itself that might affect those who are being observed, raters were present in the first half of the working day but true observations started in the second half of working day.

Social stressors. Social stressors were measured with seven (out of eight; due to item-total correlation) items of the scale developed by Frese and Zapf ${ }^{39)}$; e.g., "With some colleagues there is often conflict"). Items were answered on a 5-point Likert-scale that ranged from 1 (strongly disagree) to 5 (strongly agree); Cronbach's alpha ranged between 0.75 and 0.76 . The reliability of difference scores of social stressors, observed work stressors and job control ranged between 0.55 and 0.79 .

Body-Mass-Index. BMI $\left(\mathrm{kg} / \mathrm{m}^{2}\right)$ was calculated using self-reported height measurements and body weight by use of an electronic scale (SOEHNLE Omega 7240 PW30). Weight measurement was done by raters before observation started. Participants were weighed with clothes and without shoes.

Control variables. Regarding BMI, there are numerous confounding variables. We collected some of these potential influences like age $\mathrm{e}^{40)}$, education (proxy for social class, ${ }^{41-44)}$ ), and health related behaviour (e.g., smoking, alcohol intake, staying on a diet, exercising ${ }^{15,45)}$ ). To keep predictors in the analysis to a reasonable number, we only included control variables if they were associated with BMI (either at the first or second time or the difference scores). Therefore, we only controlled for age. Furthermore, no mean differences concerning these control variables between responders and non-responders (dropout) appeared ( $p$ between 0.12 and 0.94 ).

\section{Statistical analysis}

First, correlations between all the included variables were calculated. Second, separately, three (both A) crosssectional and B) prospective) multiple regression analyses (hierarchical regression; Ordinary Least Squares method (OLS)) predicting A) BMI and B) change in BMI were computed. We include variables in different blocks (step one to three). The method of regression was enter. Age (step 1), predictor variables (step 2; social stressors at work, job stress and control with respect to the model a), b) or c)), and the interaction term (step 3; which is indicated by b) JDC model) were entered block by block. Components of interaction were grand mean centred. Third, a joint model of all significant predictors was calculated.

\section{Response bias}

Regarding the rather small number of respondents with respect to the main study, there might be potential response bias. We therefore compared self-reported data of responders $(n=57)$ and non-responders $(n=395)$ within the main study (Time 1 and Time 2 were assessed six months earlier than the data that is used in this subsample). However, there is of course a delay in time and with respect to stressors and work related control different methods were used. There were no differences in employment rate between responders $(M=98.00)$ and non-responders $(M=96.84)$ and the number of children $\left(M_{\text {responders }}=0.12\right.$, $\left.M_{\text {non-responders }}=0.01\right)$ a year later. Neither at the beginning of the study nor a year later did differences for social stressors and work related control occur. Nevertheless, contrary to expectations, responders seem to have slightly more time pressure at the beginning of the study $(M=3.71)$ than non-responders $(M=3.27 ; \mathrm{t}(448)=-3.53$, $p=0.001$, two-tailed) but not a year later $\left(M_{\text {responders }}=3.55\right.$, $\left.M_{\text {non-responders }}=3.38\right)$. In addition self-reported BMI two years later was different in that responders $(M=23.69$; $n=40)$ reported higher BMI values than non-responders $(n=165 ; M=21.93 ; \mathrm{t}(203)=-2.67, p=0.008$, two-tailed $)$.

\section{Results}

Nineteen participants (out of 57) did not participate 


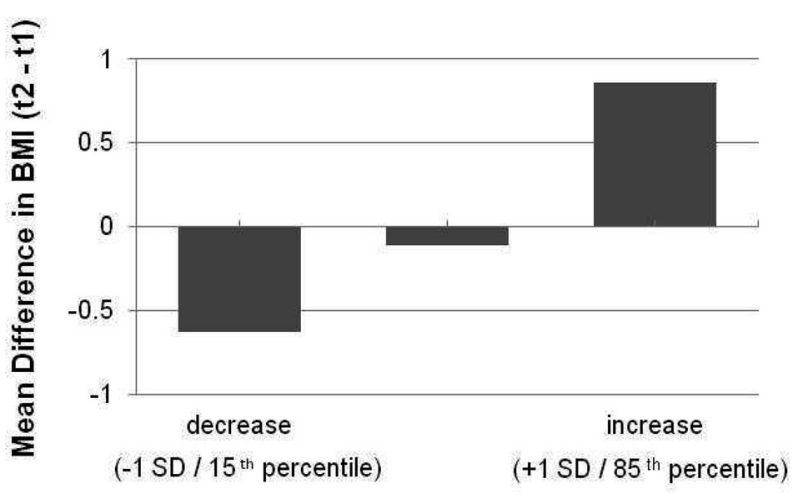

Difference in Social Stressors (t2 - t1)

Fig. 1. Difference in BMI as a function of social stressors at work.

at follow-up. A test for potential bias compared whether dropouts differed from others in baseline measurement. There was no significant difference in study variables ( $p$ was between 0.22 and 0.95 ).

\section{Correlations}

Descriptive statistics are shown in Table 1. As expected, BMI at baseline is highly correlated with BMI at followup ( $r=0.92, p<0.01)$, indicating considerable stability of inter-individual differences in body weight.

\section{Regression Analyses}

Table 2 shows results of the regression analysis. At baseline, there is only a positive effect of social stressors on BMI.

Longitudinally, an increase in social stressors is associated with an increase in BMI too (Fig. 1). Concerning the JDC model, decreasing control (and only marginally significantly increasing demands) predicts increasing BMI (Fig. 2). Thus, job control, while not correlated with baseline and follow-up BMI, did predict change in BMI, however, no significant interaction emerged. Both social stressors at work and control could explain a significant amount of variance in change of BMI - confirming hypotheses 1 and 2.2.

\section{Discussion}

The current study investigates associations between working conditions and BMI. Thereby, social stressors at work and participant's height were the only self-report measures included. In addition, we concentrated on female employees in the first months of their professional life to preclude the healthy worker effect ${ }^{33}$, 34). Change in social

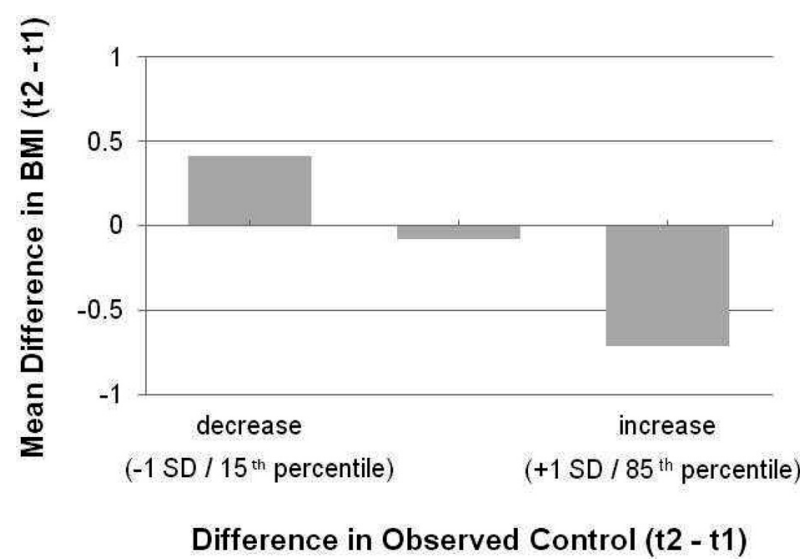

Fig. 2. Difference in BMI as a function of observed control at work.

stressors and job control predict change in BMI over one year - confirming the importance of work stress in the development of obesity. Across the year of observation, work stress might have changed energy intake (e.g., increasing drive to eat; ${ }^{16,45-47)}$ ), decreased physical activity ${ }^{45,48)}$, and stimulated the organism to accumulate fat to face stressful demands ${ }^{29)}$.

Results are in line with previous research underlining the importance of social stressors within the scope of stress as an offence to self ${ }^{49-51)}$. People strive to maintain a positive sense of self ${ }^{52)}$. However, social stressors at work are common in job beginners and include attacks, making fun at the expense of other people, or a disproportional response to mistakes ${ }^{35)}$. Thereby, they imply a lack of appreciation or even disrespect and thus a threat to self ${ }^{53)}$. Especially stressful situations that involve social-evaluative threats tend to evoke an increased cortisol response ${ }^{54}$ ) and, therefore, they should be of particular importance. The release of the stress hormone cortisol might be an important physiological link between stress and body weight. Roberts et $a l .{ }^{55)}$ found daily changes in cortisol levels to predict changes in BMI, and this relationship was mediated by aspects of eating behaviour.

Regarding the JDC model, results reveal a main effect of observed control on decreasing BMI; observed demands are marginally significant. From a cross-sectional perspective, neither control nor demands were significant, which stresses the importance of investigating intra-individual shifts in variables over time. No interaction emerged reconfirming previous research ${ }^{29,56)}$. However, taking into account the lack of power due to the small sample size an existing interaction effect would be difficult to find ${ }^{57,58)}$. 


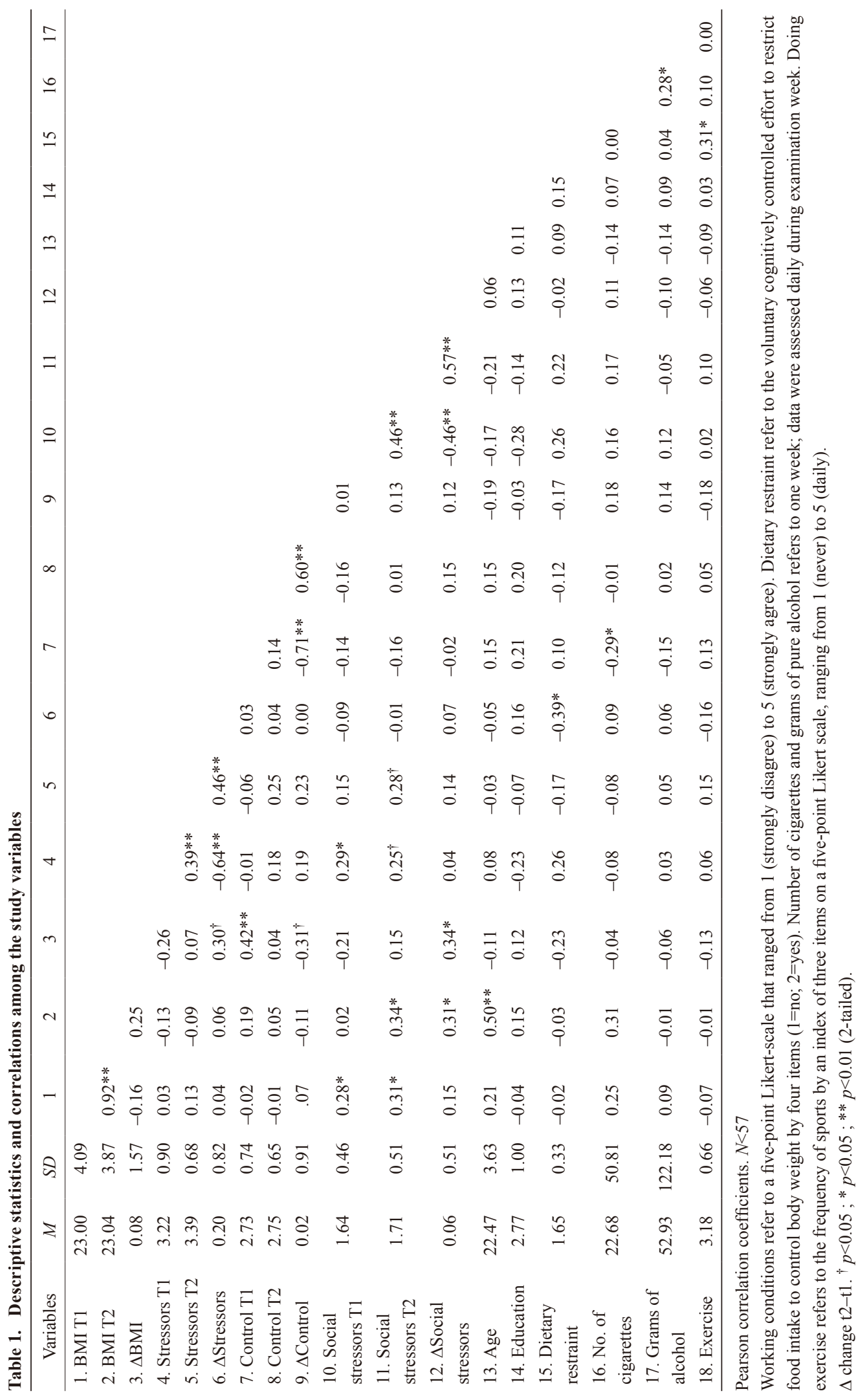


Table 2. Summary of multiple regression analysis for social stressor and the JDC model predicting BMI and change in BMI one year later

\begin{tabular}{|c|c|c|c|c|c|c|c|c|c|c|}
\hline \multirow[b]{2}{*}{ Variables } & \multicolumn{5}{|c|}{ A) BMI at baseline } & \multicolumn{5}{|c|}{ B) Change in BMI one year later } \\
\hline & $b$ & $S E b$ & $\beta$ & $\Delta R^{2}$ & $R^{2}$ & $b$ & $S E b$ & $\beta$ & $\Delta R^{2}$ & $R^{2}$ \\
\hline Step 1 & & & & & 0.04 & & & & & 0.01 \\
\hline Age & 0.24 & 0.15 & 0.21 & & & -0.05 & 0.08 & -0.11 & & \\
\hline \multicolumn{11}{|c|}{ a) Social stressors at work model } \\
\hline Step 2 & & & & $0.11 * *$ & 0.15 & & & & $0.13^{\dagger}$ & 0.14 \\
\hline Social stressors & 2.90 & 1.14 & $0.33 * *$ & & & 1.12 & 0.47 & $0.37 *$ & & \\
\hline \multicolumn{11}{|l|}{ b) JDC model } \\
\hline Step 2 & & & & 0.00 & 0.05 & & & & $0.18 *$ & 0.19 \\
\hline Observed stressors & 0.05 & 0.62 & 0.01 & & & 0.58 & 0.30 & $0.30^{\dagger}$ & & \\
\hline Observed control & -0.30 & 0.77 & -0.05 & & & -0.59 & 0.28 & $-0.31 *$ & & \\
\hline Step 3 & & & & 0.03 & 0.07 & & & & $0.02^{\dagger}$ & 0.21 \\
\hline Demands $\times$ control & -0.99 & 0.82 & -0.17 & & & 0.36 & 0.41 & 0.14 & & \\
\hline \multicolumn{11}{|c|}{ c) Joint model of job control and social stressors } \\
\hline Step 2 & & & & & & & & & $0.23 *$ & 0.24 \\
\hline Social stressors & & & & & & 1.13 & 0.45 & $0.37 *$ & & \\
\hline Observed control & & & & & & -0.58 & 0.28 & $-0.31 *$ & & \\
\hline
\end{tabular}

$N_{T 1}=55 / N_{T 2}=38$. A) cross-sectional and B) prospective multiple regression: Variables predicting BMI at baseline refer to baseline values (t1); variables predicting change in BMI refer to difference scores ( $\mathrm{t} 2-\mathrm{t} 1) . b=$ unstandardised regression coefficient. $S E b=$ standard error of unstandardised regression coefficient. $\beta=$ standardised regression coefficient. $\Delta R^{2}=$ change in explained variance. $R^{2}=$ explained variance. ${ }^{\dagger} p<0.10 .{ }^{*} p<0.05 . * * p<0.01$ (2-tailed). Post hoc power analysis (2-tailed): main effects $=68-92 \%$; interaction $=22 \%$.

Therefore some authors ${ }^{58)}$ suggest a liberal significance criterion of 0.10 to test an interaction. Thus, future research is needed.

In the joint model of social stressors and control, observed control and self-reported social stressors are associated with change in BMI. Thus, results are less subject to common method variance. Additionally, there are several reasons (e.g., timing or the abundance of potential influences) for empirical research - in cross-sectional as well as longitudinally findings - to rarely find effects of workrelated stressors on well-being or health-related outcomes explaining more than 5 to $10 \%$ of the variance ${ }^{59)}$. The joint model explained $23 \%$ of variance in change in BMI across one year. Thus, effects seem to be quite remarkable.

However, even though we measured body weight by scale we use self-reported data for height to calculate the body mass index. In consequence of social desirability, this might result in a potential bias. On the other hand, Donaldson and Grant-Vallone ${ }^{60)}$ showed that agreement among self-reports and measures of height was quite high. In addition, using BMI as a continuous and not a categorical variable should lower the impact of potential bias on the analyses ${ }^{61)}$. However, any biasing influence might especially tend towards the mean ${ }^{62)}$, restricting the variance in the BMI measures and therefore causing effects to be underestimated, rather than overestimated. Nevertheless, future research should include an objective measure of height to reduce any kind of bias.

We longitudinally investigated the effects of working conditions on change in BMI using self-report and ratings by trained observers. However, due to the complex study design, the sample size is small: observations increase the effort involved and require permission of the management, and longitudinal studies involve some dropout. Sample size implies limited power and therefore extends the risk of missing a significant effect. As a consequence, effects might have been underestimated especially regarding observed demands and the interaction of demands and control. Moreover, the power to detect interaction in regression is low $\left.{ }^{57}, 58\right)$. As we investigated only young women and only controlled for age, generalisation was restrained as well.

Confidence in difference scores has been discussed ${ }^{63,64)}$. However, there is also a great deal of support for their use under certain conditions: difference scores are appropriate when test measures are reliable ${ }^{65,66)}$ and reliability of scores exceeds 0.5 , which is true for all included psychological variables ${ }^{67}$. Future research should raise the number of measurements and estimate growth in BMI over larger periods of time.

In conclusion, results highlight the importance of social 
stressors and control at work in the context of BMI and thus, of population health.

\section{Acknowledgements}

The research reported in this article was supported by the Swiss National Science Foundation, SPP "Demain la Suisse" for the project "Working Experience and Quality of Life in Switzerland" (an in-depth study of "Stressful Experiences at Work"; principal investigator: Norbert K. Semmer) and by another grant from the Swiss National Science Foundation (1114-068280) to Norbert K. Semmer. The authors thank Lisa Weibel for her help in conducting the study.

\section{References}

1) De Vriendt T, Moreno LA, De Henauw S (2009) Chronic stress and obesity in adolescents: scientific evidence and methodological issues for epidemiological research. Nutr Metab Cardiovasc Dis 19, 511-9. [Medline] [CrossRef]

2) Darling CA, Coccia C, Senatore N (2012) Women in midlife: stress, health and life satisfaction. Stress Health 28, 31-40. [Medline] [CrossRef]

3) Luppino FS, de Wit LM, Bouvy PF, Stijnen T, Cuijpers P, Penninx BWJH, Zitman FG (2010) Overweight, obesity, and depression: a systematic review and meta-analysis of longitudinal studies. Arch Gen Psychiatry 67, 220-9. [Medline] [CrossRef]

4) Di Milia L, Mummery K (2009) The association between job related factors, short sleep and obesity. Ind Health 47 , 363-8. [Medline] [CrossRef]

5) Cedergren MI, Selbing AJ, Källén BAJ (2002) Risk factors for cardiovascular malformation - a study based on prospectively collected data. Scand J Work Environ Health 28, 12-7. [Medline] [CrossRef]

6) Guh DP, Zhang W, Bansback N, Amarsi Z, Birmingham CL, Anis AH (2009) The incidence of co-morbidities related to obesity and overweight: a systematic review and meta-analysis. BMC Public Health 9, 88. [Medline] [CrossRef]

7) Kivimäki M, Virtanen M, Elovainio M, Kouvonen A, Väänänen A, Vahtera J (2006) Work stress in the etiology of coronary heart disease - a meta-analysis. Scand J Work Environ Health 32, 431-42. [Medline] [CrossRef]

8) Murphy NF, MacIntyre K, Stewart S, Hart CL, Hole D, McMurray JJV (2006) Long-term cardiovascular consequences of obesity: 20-year follow-up of more than 15000 middle-aged men and women (the Renfrew-Paisley study). Eur Heart J 27, 96-106. [Medline] [CrossRef]

9) Finkelstein EA, DiBonaventura M, Burgess SM, Hale BC (2010) The costs of obesity in the workplace. J Occup Environ Med 52, 971-6. [Medline] [CrossRef]
10) Schmier JK, Jones ML, Halpern MT (2006) Cost of obesity in the workplace. Scand J Work Environ Health 32, 5-11. [Medline] [CrossRef]

11) Robroek SJW, Reeuwijk KG, Hillier FC, Bambra CL, van Rijn RM, Burdorf A (2013) The contribution of overweight, obesity, and lack of physical activity to exit from paid employment: a meta-analysis. Scand J Work Environ Health 39, 233-40. [Medline] [CrossRef]

12) Roos E, Laaksonen $M$, Rahkonen $O$, Lahelma E, Lallukka $\mathrm{T}$ (2013) Relative weight and disability retirement: a prospective cohort study. Scand J Work Environ Health 39, 259-67. [Medline] [CrossRef]

13) Lin TC, Verma SK, Courtney TK (2013) Does obesity contribute to non-fatal occupational injury? Evidence from the National Longitudinal Survey of Youth. Scand J Work Environ Health 39, 268-75. [Medline] [CrossRef]

14) Scott KA, Melhorn SJ, Sakai RR (2012) Effects of chronic social stress on obesity. Curr Obes Rep 1, 16-25. [Medline] [CrossRef]

15) Fried Y, Laurence GA, Shirom A, Melamed S, Toker S, Berliner S, Shapira I (2013) The relationship between job enrichment and abdominal obesity: a longitudinal field study of apparently healthy individuals. J Occup Health Psychol 18, 458-68. [Medline] [CrossRef]

16) Nishitani N, Sakakibara H (2006) Relationship of obesity to job stress and eating behavior in male Japanese workers. Int J Obes (Lond) 30, 528-33. [Medline] [CrossRef]

17) Karasek JRA (1979) Job demands, job decision latitude, and mental strain: implications for job redesign. Adm Sci Q 24, 285-308. [CrossRef]

18) Siegrist J (2002) Effort-reward imbalance at work and health. In: Historical and current perspectives on stress and health, Perrewé PL and Ganster DC (Eds.), 261-91, Emerald Group Publishing, New York.

19) Ishizaki M, Nakagawa $H$, Morikawa $Y$, Honda R, Yamada $Y$ Kawakami N, Japan Work Stress and Health Cohort Study Group (2008) Influence of job strain on changes in body mass index and waist circumference-6-year longitudinal study. Scand J Work Environ Health 34, 288-96. [Medline] [CrossRef]

20) Kouvonen A, Kivimäki M, Cox SJ, Cox T, Vahtera J (2005) Relationship between work stress and body mass index among 45,810 female and male employees. Psychosom Med 67, 577-83. [Medline] [CrossRef]

21) Overgaard D, Gyntelberg F, Heitmann BL (2004) Psychological workload and body weight: is there an association? A review of the literature. Occup Med (Lond) 54, 35-41. [Medline] [CrossRef]

22) Siegrist J, Rödel A (2006) Work stress and health risk behavior. Scand J Work Environ Health 32, 473-81. [Medline] [CrossRef]

23) Vrijkotte TGM, van Doornen LJP, de Geus EJC (1999) Work stress and metabolic and hemostatic risk factors. Psychosom Med 61, 796-805. [Medline]

24) Wardle J, Chida Y, Gibson EL, Whitaker KL, Steptoe A 
(2011) Stress and adiposity: a meta-analysis of longitudinal studies. Obesity (Silver Spring) 19, 771-8. [Medline] [CrossRef]

25) Gram Quist H, Christensen U, Christensen KB, Aust B, Borg V, Bjorner JB (2013) Psychosocial work environment factors and weight change: a prospective study among Danish health care workers. BMC Public Health 13, 43. [Medline] [CrossRef]

26) Nyberg ST, Heikkilä K, Fransson EI, Alfredsson L, De Bacquer D, Bjorner JB, Bonenfant S, Borritz M, Burr H, Casini A, Clays E, Dragano N, Erbel R, Geuskens GA, Goldberg M, Hooftman WE, Houtman IL, Jöckel KH, Kittel F, Knutsson A, Koskenvuo M, Leineweber C, Lunau T, Madsen IE, Hanson LL, Marmot MG, Nielsen ML, Nordin M, Oksanen T, Pentti J, Rugulies R, Siegrist J, Suominen S, Vahtera J, Virtanen M, Westerholm P, Westerlund H, Zins M, Ferrie JE, Theorell T, Steptoe A, Hamer M, Singh-Manoux A, Batty GD Kivimäki M, IPD-Work Consortium (2012) Job strain in relation to body mass index: pooled analysis of 160000 adults from 13 cohort studies. J Intern Med 272, 65-73. [Medline] [CrossRef]

27) Semmer NK, Grebner S, Elfering A (2004) Beyond selfreport: using observational, physiological, and situationbased measures in research on occupational stress. In: Research in Occupational Stress and Well-being, Perrewé PL and Ganster DC (Eds.), 207-63, JAI, Amsterdam.

28) Dormann C, Zapf D (2002) Social stressors at work, irritation, and depressive symptoms. Accounting for unmeasured third variables in a multi-wave study. J Occup Organ Psychol 75, 33-58. [CrossRef]

29) Berset M, Semmer NK, Elfering A, Jacobshagen N, Meier LL (2011) Does stress at work make you gain weight? A two-year longitudinal study. Scand J Work Environ Health 37, 45-53. [Medline] [CrossRef]

30) Podsakoff PM, MacKenzie SB, Lee JY, Podsakoff NP (2003) Common method biases in behavioral research: a critical review of the literature and recommended remedies. J Appl Psychol 88, 879-903. [Medline] [CrossRef]

31) Semmer NK, Zapf D, Greif S (1996) 'Shared job strain': a new approach for assessing the validity of job stress measurements. J Occup Organ Psychol 69, 293-310. [CrossRef]

32) Spector PE (2006) Method variance in organizational research: truth or urban legend? Organ Res Methods 9, 221-32. [CrossRef]

33) Garst H, Frese M, Molenaar PCM (2000) The temporal factor of change in stressor-strain relationships: a growth curve model on a longitudinal study in east Germany. J Appl Psychol 85, 417-38. [Medline] [CrossRef]

34) Zapf D, Dormann C, Frese M (1996) Longitudinal studies in organizational stress research: a review of the literature with reference to methodological issues. J Occup Health Psychol 1, 145-69. [Medline] [CrossRef]

35) Elfering A, Semmer N, Tschan F, Kälin W, Bucher A (2007) First years in job: a three-wave analysis of work experiences. J Vocat Behav 70, 97-115. [CrossRef]

36) Hellerstedt WL, Jeffery RW (1997) The association of job strain and health behaviours in men and women. Int $\mathrm{J}$ Epidemiol 26, 575-83. [Medline] [CrossRef]

37) Semmer NK, Zapf D, Dunckel H (1995) Assessing stress at work: A framework and an instrument, Office for Official Publications of the European Communities, Luxembourg.

38) Van der Doef M, Maes S (1999) The Job Demand-Control (-Support) Model and psychological well-being: a review of 20 years of empirical research. Work Stress 13, 87-114. [CrossRef]

39) Frese M, Zapf D (1987) SSS - Skala Sozialer Stressoren am Arbeitsplatz. Z Alternsforsch 41, 134-41.

40) Villareal DT, Apovian CM, Kushner RF Klein S, American Society for Nutrition NAASO, The Obesity Society (2005) Obesity in older adults: technical review and position statement of the American Society for Nutrition and NAASO, The Obesity Society. Obes Res 13, 1849-63. [Medline] [CrossRef]

41) Ball K, Crawford D (2005) Socioeconomic status and weight change in adults: a review. Soc Sci Med 60, 19872010. [Medline] [CrossRef]

42) Brunner EJ, Marmot MG, Nanchahal K, Shipley MJ, Stansfeld SA, Juneja M, Alberti KGMM (1997) Social inequality in coronary risk: central obesity and the metabolic syndrome. Evidence from the Whitehall II study. Diabetologia 40, 1341-9. [Medline] [CrossRef]

43) Harrington DW, Elliott SJ (2009) Weighing the importance of neighbourhood: a multilevel exploration of the determinants of overweight and obesity. Soc Sci Med 68, 593-600. [Medline] [CrossRef]

44) Moore CJ, Cunningham SA (2012) Social position, psychological stress, and obesity: a systematic review. J Acad Nutr Diet 112, 518-26. [Medline] [CrossRef]

45) Mouchacca J, Abbott GR, Ball K (2013) Associations between psychological stress, eating, physical activity, sedentary behaviours and body weight among women: a longitudinal study. BMC Public Health 13, 828. [Medline] [CrossRef]

46) Cropley M, Michalianou G, Pravettoni G, Millward LJ (2012) The relation of post-work ruminative thinking with eating behaviour. Stress Health 28, 23-30. [Medline] [CrossRef]

47) Groesz LM, McCoy S, Carl J, Saslow L, Stewart J, Adler N, Laraia B, Epel E (2012) What is eating you? Stress and the drive to eat. Appetite 58, 717-21. [Medline] [CrossRef]

48) Sonnentag S, Jelden S (2009) Job stressors and the pursuit of sport activities: a day-level perspective. J Occup Health Psychol 14, 165-81. [Medline] [CrossRef]

49) Kottwitz MU, Meier LL, Jacobshagen N, Kälin W, Elfering A, Hennig J, Semmer NK (2013) Illegitimate tasks associated with higher cortisol levels among male employees when subjective health is relatively low: an intra-individual analysis. Scand J Work Environ Health 39, 310-8. [Medline] [CrossRef] 
50) Pereira D, Meier LL, Elfering A (2013) Short-term effects of social exclusion at work and worries on sleep. Stress Health 29, 240-52. [Medline] [CrossRef]

51) Semmer NK, Jacobshagen N, Meier LL, Elfering A (2007) Occupational stress research: The "stress-as-offense-to self" perspective. In: Occupational health psychology: European perspectives on research, education and practice, Houdmont J and McIntyre S (Eds.), 43-60, ISMAI Publishing, Castelo da Maia.

52) Epstein SCognitive-Experiential Self-Theory (1998) In: Advanced Personality, Barone D, Hersen M, Hasselt V (Eds.), 211-38, Springer.

53) Semmer NK, Jacobshagen N, Meier LL (2006) Arbeit und (mangelnde) Wertschätzung [Work and (lack of) appreciation]. Wirtschaftspsychol 8, 87-95.

54) Dickerson SS, Kemeny ME (2004) Acute stressors and cortisol responses: a theoretical integration and synthesis of laboratory research. Psychol Bull 130, 355-91. [Medline] [CrossRef]

55) Roberts C, Troop N, Connan F, Treasure J, Campbell IC (2007) The effects of stress on body weight: biological and psychological predictors of change in BMI. Obesity (Silver Spring) 15, 3045-55. [Medline] [CrossRef]

56) Bosma H, Peter R, Siegrist J, Marmot M (1998) Two alternative job stress models and the risk of coronary heart disease. Am J Public Health 88, 68-74.

57) Aguinis H, Beaty JC, Boik RJ, Pierce CA (2005) Effect size and power in assessing moderating effects of categorical variables using multiple regression: a 30-year review. J Appl Psychol 90, 94-107. [Medline] [CrossRef]

58) Frese M (1999) Social support as a moderator of the relationship between work stressors and psychological dysfunctioning: a longitudinal study with objective measures. J Occup Health Psychol 4, 179-92. [Medline]
[CrossRef]

59) Zapf D, Semmer NK(2004) Stress und Gesundheit in Organisationen. In: Enzyklopädie der Psychologie, Themenbereich D, Band 3 Organisationspsychologie, Schuler H (Ed.), 1007-112, Hogrefe, Göttingen.

60) Donaldson SI, Grant-Vallone EJ (2002) Understanding self-report bias in organizational behavior research. J Bus Psychol 17, 245-60. [CrossRef]

61) Boström G, Diderichsen F (1997) Socioeconomic differentials in misclassification of height, weight and body mass index based on questionnaire data. Int J Epidemiol 26, 860-6. [Medline] [CrossRef]

62) Roberts RJ (1995) Can self-reported data accurately describe the prevalence of overweight? Public Health 109, 275-84. [Medline] [CrossRef]

63) Edwards JR (2001) Ten difference score myths. Organ Res Methods 4, 265-87. [CrossRef]

64) Thomas DR, Zumbo BD (2012) Difference scores from the point of view of reliability and repeated-measures ANOVA: in defense of difference scores for data analysis. Educ Psychol Meas 72, 37-43. [CrossRef]

65) Bortz J, Döring N (2006) Forschungsmethoden und Evaluation für Human- und Sozialwissenschaftler. 4th Ed., Springer, Berlin.

66) Rogosa DR (1988) Myths about longitudinal research. In: Methodological Issues in Aging Research, Schaie KW, Campbell RT, Meredith WM, Rawlings SC (Eds.), 171-209, Springer, New York.

67) Smith P, Beaton D (2008) Measuring change in psychosocial working conditions: methodological issues to consider when data are collected at baseline and one follow-up time point. Occup Environ Med 65, 288-95, quiz 295-6. [Medline] [CrossRef] 